\title{
Pengaruh Dosis Pupuk Dan Pembumbunan Terhadap Produksi Jagung( Zea mays L. )
}

\author{
Meiyana Hikmawati \\ Dosen Fakultas Pertanian, Universitas Soerjo Ngawi, Jl. Cepu Km.3, Ngawi, 63218 \\ E-mail: -
}

\begin{abstract}
The objectives of this research is the effect of fertilizer dosag and embedding on the yield of corn (Zea mays L). The method of the research use factorial design based on the Randomized Block Design with two factors of treatment. The first factor was fertilizer dosag (without fertilizer $\left(P_{0}\right)$, fertilizer dosag $250 \mathrm{~kg} / \mathrm{ha}\left(P_{1}\right)$, fertilizer dosag $500 \mathrm{~kg} / \mathrm{ha}\left(P_{2}\right)$ ) and second factor was embedding (one time embedding at age 3 week $\left(B_{1}\right)$, two time embedding at age 3 and 6 week $\left(B_{2}\right)$, three time embedding at age 3,6 and 9 week $\left(B_{3}\right)$ ) and each kombination of treatment three times replicated. The result of the research : (1) There was interaction between fertilizer dosag and embedding for parameters 100 seeds wet weight and dry weight of 100 seeds. (2) The highest yield was treatment combination P2B3 (fertilizer dosag $500 \mathrm{~kg} / \mathrm{ha}$ and three time embedding at age 3,6 and 9 week) for parameters 100 seeds wet weight and dry weight of 100 seeds .(3) The highest yield treatment fertilizer dosag treatment $P 2500 \mathrm{~kg} / \mathrm{ha}$ and embedding treatment $B 3$ two time embedding at age 3 and 6 week.
\end{abstract}

Keywords - : fertilizer dosag; embedding and interaction.

\section{PENDAHULUAN}

\section{A. Latar Belakang}

Jagung (Zea mays L.) merupakan salah satu tanaman pangan dunia yang penting, selain gandum dan padi. Sebagai sumber karbohidrat utama di Amerika Tengah dan Selatan, jagung juga menjadi alternatif sumber pangan di Amerika Serikat serta beberapa daerah di Indonesia (misalnya di Madura dan Nusa Tenggara) menggunakan jagung sebagai makanan pokok yang banyak mengandung karbohidrat. Jagung dapat tumbuh diberbagai kondisi iklim dan merupakan tanaman biji-bijian yang jumlah produksi setiap tahunnya terbesar dibanding tanaman biji-bijian yang lain (Malti et al, 2011). Selain sebagai sumber karbohidrat, jagung juga ditanam sebagai pakan ternak (hijauan maupun tongkolnya), diambil minyaknya (dari biji), dibuat tepung (dari biji, dikenal dengan istilah tepung jagung atau maizena), dan bahan baku industri (dari tepung biji dan tepung tongkolnya). Jagung yang telah direkayasa genetika juga sekarang ditanam sebagai penghasil bahan farmasi sehingga kebutuhan jagung semakin meningkat dari tahun ke tahun.

Produksi jagung di Indonesia berdasarkan data BPS (2013) menunjukkan bahwa produktivitas jagung tahun 2010 sebesar 44,36 Ku/Ha dengan produksi 18.327.636 ton. Pada tahun 2011 produktivitas jagung mengalami peningkatan menjadi 45,65 $\mathrm{Ku} / \mathrm{Ha}$. Tetapi, produksi jagung menurun menjadi 17.643.250 ton. Tahun 2012 produktivitas jagung meningkat menjadi 48,93 $\mathrm{Ku} / \mathrm{Ha}$ dengan produksi 19.377.030 ton. Pada tahun 2013, produksi jagung nasional diproyeksikan menjadi 26 juta ton pipilan kering (PK) (Setneg, 2013). Namun permasalahan yang dijumpai dalam pengembangan jagung adalah naik turunya produksi, harga, kualitas. Menurut Tangendjaja (2011) permasalahan yang sering dijumpai pada jagung lokal adalah kadar air, mikotoksin, jagung pecah dan benda asing, serta variasi kandungan gizi. Selain itu produktivitas lahan dan produksi tanaman di lahan kering masih rendah karena sebagian besar lahan kering mempunyai tingkat kesuburan rendah dan sumber air terbatas hanya tergantung pada curah hujan yang distribusinya tidak dapat diatur sesuai dengan kebutuhan tanaman (Andrianto dan Indarto, 2004).

Salah satu upaya untuk meningkatkan produksi yang tinggi adalah melalui pemberian pupuk yang berimbang. Para petani jagung saat ini lebih banyak menggunakan pupuk maupun obat-obatan kimia yang diharapkan dapat memberikan hasil yang melimpah tanpa memikirkan akibat yang akan ditimbulkan jangka panjang, Sehingga Pemerintah mulai menggalakkan program pemupukan berimbang yang secara bertahap akan mengembalikan kesuburan tanah dengan semboyan dosis 5-3-2 yang artinya menggunakan Petroganik 500kg/ha, Phonska 300kg/ha, dan Urea 200kg/ha. Pupuk petroganik merupakan pupuk yang disarankan pemerintah karena manfaat jangka panjang, untuk mengembalikan kesuburan tanah yang sekarang mengalami keadaan kritis atau hanya $66 \%$ dari total 7 juta hektar lahan pertanian yang ada di Indonesia. (Anonim, 2013).

Selain dengan pemupukan berimbang, upaya untuk mendapatkan prosuksi yang tinggi adalah dengan cara pembumbunan tanaman. Tanah yang dibumbun disekitar tanaman mempunyai maksud melindungi tanaman terhadap kekeringan, membantu tumbuhnya akar samping dan perlindungan terhadap hama dan penyakit. (Suhardi,1983). 
Website : http://agritek.unmermadiun.ac.id/index.php/agritek

\section{B. Tujuan Penelitian}

Tujuan dari penelitian ini adalah untuk mengetahui pengaruh dosis pupuk dan pembumbunan terhadap produksi jagung (Zea mays $\mathrm{L}$ ).

\section{Hipotesis}

Diduga terdapat interaksi antara dosis pupuk dan pembumbunan terhadap produksi jagung (Zea mays L).

\section{TINJAUAN PUSTAKA}

\section{A. Botani Tanaman Jagung}

Tanaman jagung terdiri atas akar, batang, daun, bunga dan biji. Tanaman jagung berakar serabut, menyebar ke samping dan ke bawah sepanjang sekitar $25 \mathrm{~cm}$. Batang berwarna hijau sampai keunguan, berbentuk bulat dengan penampang melintang 2 $2.5 \mathrm{~cm}$, tinggi tanaman bervariasi antara $125-250 \mathrm{~cm}$. Batang berbuku-buku yang dibatasi oleh ruas-ruas. Daun terdiri atas pelepah daun dan helaian daun, helaian daun memanjang dengan ujung daun meruncing, antara pelepah daun dengan helaian daun dibatasi oleh spicula yang berguna untuk menghalangi masuknya air hujan / embun ke pelepah daun. Biji tersusun rapi pada tongkol, pada setiap tanaman jagung ada sebuah tongkol, tetapi terkadang ada yang dua. Biji berkeping tunggal berderet pada tongkol. Setiap tongkol terdiri atas 10 - 14 deret, sedang setiap tongkol berdiri kurang lebih $200-400$ Butir.

Tanaman jagung mempunyai adaptasi yang luas dibandingkan dengan tanaman serealia lainnya sehingga dapat hidup pada berbagai iklim. Untuk pertumbuhan diperlukan keadaan yang cukup panas. Perkecambahan memerlukan suhu optimal $30^{\circ}-32^{\circ}$ $\mathrm{C}$, jika suhu di bawah $12.8^{\circ} \mathrm{C}$ maka akan menggangu perkecambahan sehingga dapat mempengaruhi hasil produksinya . Temperatur maksimal dari tanaman jagung mulai dari fase pertumbuhan dan perkembangan adalah $18^{0}-32^{0} \mathrm{C}$. Temperatur $35^{0}$ $\mathrm{C}$ akan menyebabkan kematian pada tanaman jagung. Suhu udara atau temperatur yang baik untuk perkecambahan adalah $12^{0}$ $\mathrm{C}$, dan fase pertumbuhan adalah $21^{\circ}-30^{\circ} \mathrm{C}$. Di daerah Asia Tenggara, fase kekeringan yang terjadi pada April-Mei akan menjadi faktor pembatas pertumbuhan tanaman jagung (Belfield dan Brown, 2008). Tanaman jagung akan dapat menghasilkan hasil panen melimpah dengan curah hujan $300 \mathrm{~mm}$ perbulan. Jika kurang dari $300 \mathrm{~mm}$ perbulan akan mengakibatkan kerusakan pada tanaman jagung, namun demikian, faktor dari kelembapan tanah juga berdampak pada berkurangnya hasil panen (Belfield dan Brown, 2008).

\section{B. Pembumbunan}

Pembumbunan merupakan teknik penimbunan tanah dipangkal rumpun tanaman sehingga menutup rimpang yang mungkin muncul dipermukaan tanah. Pembumbunan memiliki banyak manfaat bagi tanaman budidaya, pengaplikasian teknik pembumbunan biasanya digunakan pada tanaman budidaya jenis jahe, lengkuas, kunyit, dst.

Pembumbunan dapat dilakukan dengan efektif bila dilaksanakan sedini mungkin pada waktu bibit tanaman mulai menggalami pertumbuhan vegetatif. Pada saat penanaman bibit sebaiknya dilakukan pembumbunan pada lubang yang telah terisi bibit jagung, untuk menghindari serangan hama dan penyakit yang menyerang bibit tanaman. Hal ini dilakukan dengan tujuan agar tanaman yang diusahakan tidak berkompetisi dalam penyerapan unsur makanan yang terkandung di dalam tanah. Pada pembumbunan di lahan yang miring atau lahan yang berbentuk terasering harus dimulai dari lahan bagian bawah. Pembumunan dengan cara ini dimaksudkan untuk mencegah penularan serangan hama dan penyakit dari tanaman yang ditanam lebih dahulu (yang biasanya juga terserang hama dan penyakit terlebih dahulu) ke tanaman yang ditanam belakangan. Saat turun hujan,air hujan akan mengalir dari tempat penanaman dibagian atas ke bagian bawah yang berpotensi membawa penyakit lewat air.

\section{Pupuk}

Pupuk organik mengandung kadar C-Organik yang tinggi, berbentuk granule, sehingga mudah diaplikasikan serta aman dan ramah lingkungan (bebas mikroba patogen, bebas dari biji-bijian/gulma), kadar air rendah sehingga efisien untuk pengangkutan dan penyimpanan dan dikemas dalam kantong kedap air. Petroganik merupakan pupuk dasar yang sesuai dengan kesuburan tanah dan kebutuhan tanaman untuk mendapatkan hasil panen yang optimal. Untuk penggunaan Pupuk Petroganik seluruhnya diaplikasikan pada pemupukan dasar, sedangkan untuk tanaman keras diberikan pada awal dan akhir musim hujan.

Dengan Kandungan keseluruhan Kadar c-organik : 12,5\% ( Perbandingan Karbon dalam satu bahan organik ), C/N rasio 10 25 ( Perbandingan karbon dan nitrogen yang terkadung dalam bahan organik ), $\mathrm{pH} 4-8$ kadar air $4-12 \%$ aturan ini telah sesuai dengan Peraturan Menteri Pertanian tentang persyaratan teknis Pupuk Organik No: 02/pert/HK.060/2/2006 tgl 10 februari 2006. Manfaat utama pupuk Petroganik adalah menggemburkan dan menyuburkan tanah, meningkatkan daya simpan dan daya serap air, memperkaya hara makro dan mikro, sesuai untuk semua jenis tanah dan tanaman. 
Website : http://agritek.unmermadiun.ac.id/index.php/agritek

\section{III.BAHAN DAN METODE PENELITIAN}

\section{A. Waktu dan Tempat Penelitian}

Penelitian ini dilaksanakan di lahan persawahan Desa Watualang, Kabupaten Ngawi. Lokasi penelitian terletak pada ketinggian $\pm 52 \mathrm{~m}$ di atas permukaan air laut dengan jenis tanah grumusol. Suhu udara berkisar $25-35^{\circ} \mathrm{C}$. Waktu penelitian pada bulan Nopember 2017 sampai Pebruari 2018.

\section{B. Bahan dan Alat Penelitian}

Bahan-bahan yang digunakan diantaranya benih jagung varietas P-21, pupuk Petroganik, pupuk phonska, pupuk urea dan pupuk ZA untuk tambahan. Sedangkan alat-alat yang digunakan yaitu rol meter, penggaris, cangkul, sabit, hand sprayer, gembor, kayu tugal, gelas ukur, ember, timbangan, papan nama dan tali bersimpul untuk menentukan jarak tanam.

\section{Metode Penelitian}

Penelitian ini menggunakan metode faktorial dengan Rancangan Acak Kelompok (RAK) yang terdiri dari dua faktor dan 9 kombinasi perlakuan, diulang sebanyak 3 kali. Selanjutnya data yang diperoleh dari hasil pengamatan dan analisa secara statistik serta untuk membedakan antar perlakuan digunakan uji jarak berganda Duncan (DMRT) pada jenjang nyata 5\%.

Adapun masing-masing faktor tersebut :

1.FaktorPertama $\quad$ : Dosis Pemupukan $(\mathrm{P})$ terdiri dari 3 taraf yaitu :

$-\mathrm{P}_{0} \quad$ : Tanpa Pupuk ( Kontrol )

- $\mathrm{P}_{1} \quad$ : Dosis pupuk Petroganik $250 \mathrm{~kg} / \mathrm{ha}(20 \mathrm{Kg} /$ Petak $)$

- $\mathrm{P}_{2} \quad$ : Dosis pupuk Petroganik $500 \mathrm{~kg} / \mathrm{ha}(40 \mathrm{Kg} /$ Petak)

2. FaktorKedua : Pembumbunan (B) terdiri dari 3 taraf, yaitu :

- $\mathrm{B}_{1} \quad$ : Pembumbunan 1x saat umur 3 minggu

$-\mathrm{B}_{2} \quad$ : Pembumbunan $2 \mathrm{x}$ saat umur 3 dan 6 minggu

$-\mathrm{B}_{3} \quad$ : Pembumbunan 3x saat umur 3, 6 dan 9 minggu

Sehingga diperoleh kombinasi perlakuan sebagai berikut :

$\begin{array}{lll}\mathrm{P}_{0} \mathrm{~B}_{1} & \mathrm{P}_{1} \mathrm{~B}_{1} & \mathrm{P}_{2} \mathrm{~B}_{1} \\ \mathrm{P}_{0} \mathrm{~B}_{2} & \mathrm{P}_{1} \mathrm{~B}_{2} & \mathrm{P}_{2} \mathrm{~B}_{2} \\ \mathrm{P}_{0} \mathrm{~B}_{3} & \mathrm{P}_{1} \mathrm{~B}_{3} & \mathrm{P}_{2} \mathrm{~B}_{3}\end{array}$

\section{IV.PELAKSANAAN PERCOBAAN}

\section{A. Persiapan Lahan}

Pengolahan tanah bertujuan untuk memperoleh struktur tanah yang remah dan konsistensi gembur, memperbaiki aerasi tanah sehingga akar jagung dapat tumbuh dengan sempurna serta memberantas tumbuhan pengganggu. Tahap I dilakukan sebelum tanam, dengan cara dicangkuli sistem kering untuk membentuk petakan dan meratakan bedengan-bedengan tanah bekas penanaman melon. Pada pengolahan tanah tahap II dilakukan 2 hari sebelum tanam dengan cara dicangkuli berlawanan dari arah pengolahan tanah tahap I dan diratakan. Pada lahan dibuat cuklakan / saluran air dengan jarak $30 \mathrm{~cm}$, Lebar petakan dibuat ukuran $\pm 250 \times 250 \mathrm{~cm}$ dan tiap blok di buat 9 petak percobaan dengan ukuran yang sama, kemudian ditugal sedalam $5-10 \mathrm{~cm}$ dengan jarak antara per lubang tanaman $\pm 50 \times 50 \mathrm{~cm}$.

\section{B. Penanaman}

Penanaman dilakukan dengan tugal berdiameter 5-10 cm. Dibagian ujung tugal dibuat lancip berbentuk taji sepanjang 3-4 $\mathrm{cm}$. Pada setiap lubang diisi 3 butir biji jagung. Setelah 7 hari dilakukan penjarangan pada tanaman yang tumbuh lebih dari satu agar tidak terjadi persaingan penyerapan air dan unsur hara dalam tanah.

\section{Pemupukan}

Pemupukan dilakukan satu hari sebelum tanam. Tanah diairi sebelum ditugal. Pembuatan lubang tanam dan lubang pupuk dengan cara ditugal dengan jarak tanam $50 \mathrm{~cm} \times 50 \mathrm{~cm}$ (antara 2 tanaman dalam petak perlakuan). Pemupukan dasar menggunakan petroganik dengan cara disebar ke setiap petak sebelum pengolahan tanah tahap II agar pupuk dasar petroganik dapat tercampur dengan tanah. Kemudian ditambahkan pupuk phonska dan urea yang telah dicampur menjadi satu dengan perbandingan $3: 2( \pm 3 \mathrm{~kg}$ phonska, $2 \mathrm{~kg}$ urea) diberikan saat tanam dengan cara ditugal di samping benih dalam baris tanaman dengan jarak $10 \mathrm{~cm}$. Lubang yang sudah terisi pupuk ditutup dengan tanah. Pupuk susulan I diberikan pada jagung berumur 15 - $20 \mathrm{HST}$, dengan dosisi $150 \mathrm{~kg} / \mathrm{ha}$ PHONSKA ditambah dengan $75 \mathrm{~kg}$ Urea/ha. Dan dilakukan kembali pemupukan menggunakan Za setelah 30 hst agar meningkatkan jumlah dan kwalitas tongkol. 
Website : http://agritek.unmermadiun.ac.id/index.php/agritek

\section{Penyiangan dan Pembumbunan}

Untuk memperoleh hasil yang tinggi, pertanaman harus bersih dari segala macam tumbuhan atau rumput pengaggu. Penyiangan di lakukan dengan tangan dan cangkul sebanyak 3 kali. Penyiangan pertama dilakukan pada saat tanaman berumur 3 minggu sekaligus pembumbunan ke 1. Penyiangan kedua dilakukan pada umur 6 minggu sekaligus pembumbunan ke-2 dan penyiangan yang ketiga dilakukam pada umur 9 minggu sekaligus pembumbunan.

\section{E. Pengairan}

Pengaturan irigasi dilakukan dengan menggunakan got-got yang mengelilingi petak atau bedengan percobaan. Pada awal tanam pengairan dilakukan dengan cara menggenangi bedengan sampai penuh sebelum penanaman agar kondisi tanahnya lembab. Pada saat pertumbuhan tanaman, pengairan dilakukan setiap 5 - 6 hari sekali pada sore hari hingga malam hari dikarenakan kondisi cuaca yang panas pada siang hari akibat musim kemarau sehingga tanaman lebih banyak membutuhkan air dan penyerapan air dapat terserap dengan baik oleh tanah pada malam hari.

\section{F. Pengendalian Hama Penyakit}

Dalam kegiatan penelitian ini hama yang muncul selama penanaman adalah ulat daun yang muncul pada umur tanaman 20 hst untuk pembasmiannya dilakukan dengan penyemprotan insektisida. Tanaman jagung dimonitor setiap satu minggu dan dilakukan penyemprotan apabila melihat gejala-gejala adanya hama dan penyakit lain.

\section{G. Pemanenan}

Jagung dipanen setelah berumur 100 hari yang ditunjukkan dengan tanda-tanda antara lain : daun sudah menguning, biji sudah sedikit mengeras dan kelobot sudah menguning.

\section{H. Pengamatan}

1. Pertumbuhan

a) Tinggi tanaman $(\mathrm{cm})$

Tinggi tanaman di ukur dari permukaan tanah sampai ujung daun pada saat tanaman berumur 15 hari, 30 hari dan 45 hari setelah tanam.

b) Jumlah daun

Jumlah daun yang telah membuka pada umur 15 hari, 30 hari dan 45 hari setelah panen.

2. Produksi

a) Jumlah biji per tongkol penuh

Jumlah biji per tongkol tanaman dihitung pada waktu panen yaitu barisan biji yang tersusun penuh diambil dari tanaman sampel.

b) Jumlah berat basah tongkol tanpa klobot per petak (gram)

Diukur dengan menimbang seluruh jagung per petak tanaman setelah dipanen tanpa dikeringkan dengan sinar matahari satu hari setelah panen (kering angin).

c) Jumlah berat kering tongkol tanpa klobot per petak (gram)

Diukur dengan menimbang seluruh jagung per petak tanaman setelah dipanen dan dikeringkan dengan sinar matahari sampai mencapai berat konstan dengan kadar air $14 \%$.

d) Jumlah Berat Basah 100 biji (gram)

Diukur dengan menimbang 100 biji basah dilakukan setelah dipanen tanpa dikeringkan dengan sinar matahari satu hari setelah panen (kering angin)

e) Jumlah Berat Kering 100 biji (gram)

Diukur dengan menimbang 100 biji kering dilakukan setelah dipanen dan dikeringkan dengan sinar matahari sampai mencapai berat konstan dengan kadar air $14 \%$.

\section{HASIL DAN PEMBAHASAN}

\section{A. Tinggi Tanaman (cm)}

Dari hasil analisis sidik ragam menunjukkan bahwa antara perlakuan dosis pupuk petroganik dan pembumbunan tidak menunjukkan adanya interaksi. Hasil pengamatan pengaruh perlakuan dosis pupuk petroganik dan pembumbunan terhadap tinggi tanaman jagung ditunjukkan pada tabel di bawah ini. 
Website : http://agritek.unmermadiun.ac.id/index.php/agritek

Tabel 1. Pengaruh Perlakuan Dosis Pupuk Petroganik dan Pembumbunan terhadap Tinggi Tamanan (cm).

\begin{tabular}{|c|c|c|c|}
\hline \multirow{2}{*}{ Perlakuan } & \multicolumn{3}{|c|}{ Rata-rata tinggi tanaman (cm) } \\
\hline & $\begin{array}{c}\text { Umur } \\
15 \text { HST }\end{array}$ & $\begin{array}{c}\text { Umur } \\
\text { 30 HST }\end{array}$ & $\begin{array}{c}\text { Umur } \\
45 \text { HST }\end{array}$ \\
\hline \multicolumn{4}{|c|}{ Dosis Petroganik (P) } \\
\hline $\mathrm{P} 0$ & $28,76 \mathrm{c}$ & $91,04 \mathrm{c}$ & $107,87 \mathrm{~b}$ \\
\hline $\mathrm{P} 1$ & $34,10 \mathrm{~b}$ & $100,93 \mathrm{~b}$ & $113,64 \mathrm{~b}$ \\
\hline $\mathrm{P} 2$ & $37,27 \mathrm{a}$ & $110,62 \mathrm{a}$ & 127,22 a \\
\hline \multicolumn{4}{|c|}{ Pembumbunan (B) } \\
\hline B1 & $32,58 \mathrm{a}$ & $97,64 \mathrm{~b}$ & $111,82 \mathrm{~b}$ \\
\hline B2 & 33,38 a & $99,49 \mathrm{~b}$ & $116,29 \mathrm{ab}$ \\
\hline B3 & $34,17 \mathrm{a}$ & $105,47 \mathrm{a}$ & $120,62 \mathrm{a}$ \\
\hline
\end{tabular}

Keterangan : angka-angka pada kolom yang sama yang diikuti huruf yang sama menunjukkan tidak berbeda nyata menurut uji Duncan taraf $5 \%$.

Tabel di atas menunjukkan bahwa pada umur 15 hst perlakuan dosis pupuk petroganik menyebabkan beda nyata terhadap tinggi tanaman jagung sedangkan perlakuan pembumbunan tidak menyebabkan beda nyata. Perlakuan dosis pupuk petroganik yang memberikan pertumbuhan paling baik terhadap tinggi tanaman jagung adalah perlakuan $\mathrm{P}_{2}$ (dosis pupuk petroganik 500 $\mathrm{kg} / \mathrm{ha}$ setara dengan $40 \mathrm{~kg} /$ petak) dengan rata-rata tinggi tanaman $37,27 \mathrm{~cm}$ yang berbeda nyata dengan perlakuan lainnya. Sedangkan tinggi tanaman terendah pada perlakuan $\mathrm{P}_{0}$ (tanpa dipupuk petroganik) dengan rata-rata tinggi tanaman $28,76 \mathrm{~cm}$. Perlakuan pembumbunan yang memberikan pertumbuhan paling baik terhadap tinggi tanaman jagung adalah perlakuan $\mathrm{B}_{3}$ (pembumbunan 3 kali pada umur 3, 6, dan 9 minggu) dengan rata-rata tinggi tanaman $34,17 \mathrm{~cm}$ yang tidak berbeda nyata dengan perlakuan lainnya. Sedang tinggi terendah pada perlakuan $\mathrm{B}_{1}$ (Pembumbunan 1 kali pada umur 3 minggu) dengan ratarata tinggi tanaman $32,58 \mathrm{~cm}$.

Pada umur 30 hst perlakuan dosis pupuk petroganik dan pembumbunan menyebabkan beda nyata terhadap tinggi tanaman jagung. Perlakuan dosis pupuk petroganik yang memberikan pertumbuhan paling baik terhadap tinggi tanaman jagung adalah perlakuan $\mathrm{P}_{2}$ (dosis pupuk petroganik $500 \mathrm{~kg} / \mathrm{ha}$ setara dengan $40 \mathrm{~kg} /$ petak) dengan rata-rata tinggi tanaman $110,62 \mathrm{~cm}$ yang berbeda nyata dengan perlakuan lainnya. Sedangkan tinggi terendah pada perlakuan $\mathrm{P}_{0}$ (tanpa dipupuk petroganik) dengan ratarata tinggi tanaman $91,04 \mathrm{~cm}$. Perlakuan pembumbunan yang memberikan pertumbuhan paling baik terhadap tinggi tanaman jagung adalah $\mathrm{B}_{3}$ (pembumbunan 3 kali pada umur 3,6 dan 9 minggu) dengan rata-rata 105,47 cm yang berbeda nyata dengan perlakuan $\mathrm{B}_{1}$ tapi tidak berbeda nyata dengan perlakuan $\mathrm{B}_{2}$. Sedangkan tinggi terendah pada perlakuan $\mathrm{B}_{1}$ (pembumbunan 1 kali pada umur 3 minggu) dengam rata-rata $97,64 \mathrm{~cm}$ yang berbeda nyata dengan $\mathrm{B}_{3}$ tetapi tidak berbeda nyata dengan $\mathrm{B}_{2}$.

Pada umur 45 hst perlakuan dosis pupuk petroganik dan pembumbunan menyebabkan beda nyata terhadap tinggi tanaman jagung. Perlakuan dosis pupuk petroganik yang memberikan pertumbuhan paling baik terhadap tinggi tanaman jagung adalah perlakuan $\mathrm{P}_{2}$ (dosis pupuk petroganik $500 \mathrm{~kg} / \mathrm{ha}$ setara dengan $40 \mathrm{~kg} /$ petak) dengan rata-rata tinggi tanaman $127,22 \mathrm{~cm}$ yang berbeda nyata dengan perlakuan lainnya. Sedangkan tinggi terendah pada perlakuan $\mathrm{P}_{0}$ (tanpa dipupuk petroganik) dengan ratarata tinggi tanaman $107,87 \mathrm{~cm}$ yang berbeda nyata dengan perlakuan $\mathrm{P}_{2}$ tetapi tidak berbeda nyata dengan perlakuan $\mathrm{P}_{1}$. Perlakuan pembumbunan yang memberikan pertumbuhan paling baik terhadap tinggi tanaman jagung adalah $B_{3}$ (pembumbunan 3 kali pada umur 3, 6 dan 9 minggu) dengan rata-rata 120,62 cm yang berbeda nyata dengan perlakuan $B_{1}$ tetapi tidak berbeda nyata dengan $\mathrm{B}_{2}$. Sedangkan tinggi terendah pada perlakuan $\mathrm{B}_{1}$ (pembumbunan 1 kali pada umur 3 minggu) dengam rata-rata $111,82 \mathrm{~cm}$ yang berbeda nyata dengan $\mathrm{B}_{3}$ tetapi tidak berbeda nyata dengan $\mathrm{B}_{2}$.

Berdasarkan penelitian menunjukkan bahwa penambahan dosis petroganik berpengaruh terhadap pertumbuhan tinggi tanaman jagung. Perbedaan tersebut disebabkan kandungan dari pupuk petroganik yang bersifat menggemburkan tanah dan kandungan $\mathrm{C} / \mathrm{N}$ (perbandingan karbon dan nitrogen dalam bahan organik) yang terkandung dalam pupuk petroganik merupakan unsur yang di butuhkan tanaman untuk mempercepat dan meningkatkan tinggi tanaman, jumlah daun, pembungaan dan pembentukan biji. Unsur nitrogen diperlukan oleh tanaman jagung dengan dosis $15-20 \mathrm{~kg} / \mathrm{ha}$ pada awal pertumbuhan, serta diperlukan untuk pembentukan bunga dan pengisian biji pada periode vegetatif serta membuat tanaman jagung lebih hijau segar, mempercepat dan meningkatkan pertumbuhan tanaman dan tinggi tanaman

Perlakuan pembumbunan yang juga bermanfaat memberikan ruang aerasi tanah, sehingga tanah di daerah sekitar tanaman gembur dan memudahkan akar tanaman menyerap unsur hara dan air. Penyerapan unsur hara tersebut berpengaruh juga pada tanaman jagung karena tanaman jagung memerlukan intensitas cahaya matahari yang lebih tinggi sehingga tanaman ini dapat membentuk rantai carbon sebanyak 4 buah dalam menambat karbon dioksida $\left(\mathrm{CO}_{2}\right)$ dalam melangsungkan fotosintesis (Salisburi dan Ross, 1995). 
Website : http://agritek.unmermadiun.ac.id/index.php/agritek

\section{B. Jumlah Daun}

Dari hasil analisis sidik ragam menunjukkan bahwa antara perlakuan dosis pupuk petroganik dan pembumbunan tidak menunjukkan adanya interaksi terhadap jumlah daun pada umur pengamatan 15 hst, 30 hst, dan 45 hst. Hasil pengamatan ratarata jumlah daun tanaman pada umur $15 \mathrm{hst}, 30 \mathrm{hst}$, dan $45 \mathrm{hst}$ dapat di lihat pada tabel 2.

Tabel 2. Pengaruh Perlakuan Dosis Pupuk Petroganik dan Pembumbunan terhadap Jumlah Daun.

\begin{tabular}{|c|c|c|c|}
\hline \multirow{2}{*}{ Perlakuan } & \multicolumn{3}{|c|}{ Jumlah Daun } \\
\hline & $\begin{array}{c}\text { Umur } \\
15 \text { HST }\end{array}$ & $\begin{array}{c}\text { Umur } \\
30 \text { HST }\end{array}$ & $\begin{array}{c}\text { Umur } \\
45 \text { HST }\end{array}$ \\
\hline \multicolumn{4}{|c|}{ Dosis Petroganik (P) } \\
\hline $\mathrm{P} 0$ & $6,09 \mathrm{a}$ & $10,69 \mathrm{~b}$ & $11,82 \mathrm{c}$ \\
\hline $\mathrm{P} 1$ & $6,38 \mathrm{a}$ & $11,84 a b$ & $14,09 \mathrm{~b}$ \\
\hline $\mathrm{P} 2$ & $6,69 \mathrm{a}$ & $12,29 \mathrm{a}$ & $15,87 \mathrm{a}$ \\
\hline \multicolumn{4}{|c|}{ Pembumbunan (B) } \\
\hline B1 & $6,40 \mathrm{a}$ & $11,67 \mathrm{a}$ & $13,29 \mathrm{a}$ \\
\hline B2 & $6,42 \mathrm{a}$ & $12,16 \mathrm{a}$ & $14,00 \mathrm{a}$ \\
\hline B3 & $6,33 \mathrm{a}$ & $11,00 \mathrm{a}$ & $14,49 \mathrm{a}$ \\
\hline
\end{tabular}

Keterangan : angka yang didampingi huruf yang sama menunjukkan tidak beda nyata (Duncan's Test $5 \%$ ).

Tabel 2 menunjukkan bahwa pada umur 15 hst perlakuan dosis pupuk petroganik dan pembumbunan tidak menyebabkan beda nyata terhadap jumlah daun tanaman jagung. Perlakuan dosis pupuk petroganik yang memberikan pertumbuhan paling baik terhadap jumlah daun tanaman jagung adalah perlakuan $\mathrm{P}_{2}$ (dosis pupuk petroganik $500 \mathrm{~kg} / \mathrm{ha}$ setara dengan $40 \mathrm{~kg} /$ petak) dengan rata-rata jumlah daun 6,69 helai yang tidak berbeda nyata dengan perlakuan lainnya. Sedangkan jumlah daun terendah pada perlakuan $\mathrm{P}_{0}$ (tanpa dipupuk petroganik) dengan rata-rata jumlah daun 6,09 helai. Perlakuan pembumbunan yang memberikan pertumbuhan paling baik terhadap jumlah daun tanaman jagung adalah perlakuan $\mathrm{B}_{2}$ (pembumbunan 2 kali pada umur 3 dan 6 minggu) dengan rata-rata jumlah daun 6,42 helai yang tidak berbeda nyata dengan perlakuan lainnya. Sedang jumlah daun terendah pada perlakuan $\mathrm{B}_{3}$ (Pembumbunan 3 kali pada umur 3, 6 dan 9 minggu) dengan rata-rata jumlah daun 6,33 helai.

Pada umur 30 hst perlakuan dosis pupuk petroganik menyebabkan beda nyata terhadap jumlah daun pada tanaman jagung. Sedangkan perlakuan pembumbunan tidak menyebabkan beda nyata terhadap jumlah daun tanaman jagung. Perlakuan dosis pupuk petroganik yang memberikan pertumbuhan paling baik terhadap jumlah daun jagung adalah perlakuan $\mathrm{P}_{2}$ (dosis pupuk petroganik $500 \mathrm{~kg} / \mathrm{ha}$ setara dengan $40 \mathrm{~kg} /$ petak) dengan rata-rata jumlah daun 12,29 helai yang berbeda nyata dengan perlakuan $\mathrm{P}_{0}$ tetapi tidak berbeda nyata dengan perlakuan $\mathrm{P}_{1}$. Sedangkan jumlah daun terendah pada perlakuan $\mathrm{P}_{0}$ (tanpa dipupuk petroganik) dengan rata-rata jumlah daun 10,69 helai yang berbeda nyata dengan $\mathrm{P}_{2}$ tetapi tidak berbeda nyata dengan $P_{1}$. Perlakuan pembumbunan yang memberikan pertumbuhan paling baik terhadap jumlah daun tanaman jagung adalah $B_{2}$ (pembumbunan 2 kali pada umur 3 dan 6 minggu) dengan rata-rata 12,16 helai yang tidak berbeda nyata dengan perlakuan lainnya. Sedangkan jumlah daun terendah pada perlakuan $B_{3}$ (pembumbunan 3 kali pada umur 3, 6 dan 9 minggu) dengam ratarata 11,00 helai.

Pada umur 45 hst perlakuan dosis pupuk petroganik menyebabkan beda nyata terhadap jumlah daun pada tanaman jagung. Sedangkan perlakuan pembumbunan tidak menyebabkan beda nyata terhadap jumlah daun tanaman jagung. Perlakuan dosis pupuk petroganik yang memberikan pertumbuhan paling baik terhadap jumlah daun jagung adalah perlakuan $\mathrm{P}_{2}$ (dosis pupuk petroganik $500 \mathrm{~kg} / \mathrm{ha}$ setara dengan $40 \mathrm{~kg} /$ petak) dengan rata-rata jumlah daun 15,87 helai yang berbeda nyata dengan perlakuan lainnya. Sedangkan jumlah daun terendah pada perlakuan $\mathrm{P}_{0}$ (tanpa dipupuk petroganik) dengan rata-rata jumlah daun 11,82 helai. Perlakuan pembumbunan yang memberikan pertumbuhan paling baik terhadap jumlah daun tanaman jagung adalah $\mathrm{B}_{3}$ (pembumbunan 3 kali pada umur 3,6 dan 9 minggu) dengan rata-rata 14,49 helai yang tidak berbeda nyata dengan perlakuan lainnya. Sedangkan jumlah daun terendah pada perlakuan $\mathrm{B}_{1}$ (pembumbunan 1 kali pada umur 3 minggu) dengam rata-rata 13,29 helai.

Penambahan dosis petroganik menyebabkan bertambah pula jumlah daun jagung, karena daun adalah tempat proses fotosintesis yang menghasilkan zat makanan utama guna pertumbuhan. Dengan memberikan nitrogen akan meningkatkan pertumbuhan vegetatif diantaranya adalah daun, semakin tinggi luas permukaan daun maka akan semakin tinggi pertumbuhan dan hasil. Menurut Harjadi (1991) besarnya jumlah daun dan luas daun akan berakibat tidak berimbangnya periode vegetatif dan generatif. Selain menambah unsur hara dari sumber pupuk petroganik maka akan mampu menciptakan konsisi fisik tanah 
Website : http://agritek.unmermadiun.ac.id/index.php/agritek

yang ideal bagi pertumbuhan tanaman. Dengan aerasi tanah yang seimbang karena pembumbunan akan mendorong penyerapan hara menjadi lebih baik dan salah satunya adalah terbentuknya daun sebagai tempat fotosintesis.

Penerapan teknik pembumbunan yang tepat akan menghasilkan perkembangan yang optimal dari tanaman budidaya. Pembumbunan dapat dilakukan dengan efektif bila dilaksanakan sedini mungkin pada waktu bibit tanaman mulai menggalami pertumbuhan vegetatif. Pada periode vegetatif tanaman terjadi perkembangan akar, daun dan batang. Pada saat penanaman bibit sebaiknya dilakukan pembumbunan pada lubang yang telah terisi bibit jagung, untuk menghindari serangan hama dan penyakit yang menyerang bibit tanaman. Hal ini dilakukan dengan tujuan agar tanaman yang diusahakan tidak berkompetisi dalam penyerapan unsur makanan yang terkandung di dalam tanah.

\section{Jumlah Biji Per Tongkol Penuh}

Hasil analisis sidik ragam menunjukkan bahwa antara perlakuan dosis pupuk petroganik dan pembumbunan terhadap ratarata jumlah biji per tongkol penuh per tanaman jagung tidak menunjukkan adanya interaksi. Hasil pengamatan dosis pupuk petroganik dan pembumbunan terhadap rata-rata jumlah biji per tongkol penuh tanaman jagung ditunjukkan pada tabel dibawah ini.

Tabel 3a. Pengaruh Perlakuan Dosis Pupuk Petroganik terhadap Jumlah Biji per Tongkol Penuh

\begin{tabular}{ccc}
\hline Perlakuan & Rata-rata Jumlat Biji per Tongkol Penuh \\
\hline Dosis Petroganik (P) & & $\mathrm{b}$ \\
P0 & 480,58 & $\mathrm{~b}$ \\
P1 & 485,04 & $\mathrm{a}$ \\
P2 & 511,11 & \\
\hline Keterangan : angka yang didampingi huruf yang sama menunjukkan tidak beda nyata (Duncan's Test 5\%).
\end{tabular}

Tabel di atas menunjukkan bahwa perlakuan antara $\mathrm{P}_{2}$ berbeda nyata dengan perlakuan $\mathrm{P}_{0}$, Pelakuan $\mathrm{P}_{2}$ berbeda nyata dengan perakuan $\mathrm{P}_{1}$, dan perlakuan $\mathrm{P}_{0}$ berbeda nyata dengan perlakuan $\mathrm{P}_{1}$. Pengaruh perlakuan dosis pupuk petroganik terhadap rata-rata jumlah biji per tongkol penuh tanaman jagung tertinggi pada perlakuan $\mathrm{P}_{2}$ yaitu dosis pemupukan $500 \mathrm{~kg} / \mathrm{ha}$ (setara $40 \mathrm{~kg} / \mathrm{petak}$ ) sebesar 511,11. Sedangkan rata-rata jumlah biji per tongkol penuh tanaman jagung yang paling terendah sebesar 480,58 di capai pada perlakuan $\mathrm{P}_{0}$ yaitu perlakuan tanpa pemupukan petroganik.

Adanya perbedaan jumlah biji per tongkol penuh pada tanaman jagung karena penambahan dosis petroganik menyebabkan bertambah pula jumlah daun jagung, karena daun adalah tempat proses fotosintesis yang menghasilkan zat makanan utama guna pertumbuhan. Dengan memberikan nitrogen akan meningkatkan pertumbuhan vegetative diantaranya adalah daun, semakin tinggi luas permukaan daun maka akan semakin tinggi pertumbuhan dan hasil yang di peroleh. Menurut Harjadi (1991) besarnya jumlah daun dan luas daun akan berakibat tidak berimbangnya periode vegetatif dan generatif. Selain menambah unsur hara dari sumber pupuk petroganik juga akan mampu menciptakan kondisi fisik tanah yang ideal bagi pertumbuhan tanaman.

Tabel 3b. Pengaruh Perlakuan Pembumbunan terhadap Jumlah Biji per Tongkol Penuh

\begin{tabular}{ccc}
\hline Perlakuan & Rata-rata Jumlah Biji per Tongkol Penuh \\
\hline Pembumbunan (B) & 482,24 & $\mathrm{~b}$ \\
B1 & 492,84 & $\mathrm{ab}$ \\
B2 & 501,64 & $\mathrm{a}$ \\
B3 & \\
\hline Keterangan : angka yang didampingi huruf yang sama menunjukkan tidak beda nyata (Duncan's Test $5 \%)$.
\end{tabular}

Dari tabel di atas menunjukkan bahwa antar perlakuan menunjukkan perbedaan yang nyata. Pengaruh perlakuan pembumbunan terhadap rata-rata jumlah biji per tongkol penuh tanaman jagung tertinggi pada perlakuan $B_{3}$ yaitu pembumbunan 3 kali pada umur 3,6, dan 9 minggu sebesar 501,64. Sedangkan rata-rata jumlah biji per tongkol penuh tanaman jagung yang paling terendah sebesar 482,24 dicapai pada perlakuan $\mathrm{B}_{1}$ yaitu perlakuan pembumbunan 1 kali pada umur 3 minggu saja.

Salah satu manfaat teknik pembumbunan pada tanaman jagung adalah memberikan media tumbuh yang baik bagi akar tanaman pada saat pertumbuhan awal dan mempermudah peresapan pupuk ke dalam tanah sehingga mempercepat tanaman mengabsorbsi pupuk tersebut. Dengan mempermudah peresapan pupuk dalam tanah akan memberikan unsur hara tambahan 
Website : http://agritek.unmermadiun.ac.id/index.php/agritek

yang diperlukan oleh tanaman dalam bentuk zat-zat organik yang nantinya akan disimpan dalam biji-biji tanaman yang digunakan sebagai tempat penimbun.

\section{Jumlah Berat Basah per Tongkol Tanpa Klobot (gram)}

Berdasarkan hasil analisis menunjukkan bahwa antara perlakuan dosis pupuk petroganik dan pembumbunan terhadap ratarata berat basah per tongkol tiap petak tanaman jagung tidak menunjukkan adanya interaksi. Hasil pengamatan dosis pupuk petroganik dan pembumbunan terhadap rata-rata jumlah berat basah per tongkol tanpa klobot tanaman jagung ditunjukkan pada tabel di bawah ini.

\begin{tabular}{cc} 
Tabel 4a. Pengaruh Perlakuan Dosis Pupuk Petroganik terhadap Jumlah Berat Basah per Tongkol tanpa klobot (gram). \\
\hline Perlakuan & $\begin{array}{c}\text { Rata-rata Berat Basah per Tongkol } \\
\text { Tanpa Klobot (gram) }\end{array}$ \\
\hline
\end{tabular}

\begin{tabular}{ccc}
$\begin{array}{c}\text { Dosis Petroganik (P) } \\
\text { P0 }\end{array}$ & 159,27 & $\mathrm{c}$ \\
P1 & 226,42 & $\mathrm{~b}$ \\
P2 & 249,96 & $\mathrm{a}$ \\
\hline Keterangan : angka yang didampingi huruf yang sama menunjukkan tidak beda nyata (Duncan's Test 5\%).
\end{tabular}

Tabel di atas menunjukkan bahwa perlakuan antara $P_{1}$ berbeda nyata dengan perlakuan $P_{0}$, perlakuan $P_{2}$ berbeda nyata dengan perakuan $P_{0}$ dan perlakuan $P_{2}$ berbeda nyata dengan perlakuan $P_{1}$. Pengaruh perlakuan dosis pupuk petroganik terhadap rata-rata berat basah per tongkol tanpa klobot tanaman jagung tertinggi pada perlakuan $\mathrm{P}_{2}$ yaitu dosis pemupukan $500 \mathrm{~kg} / \mathrm{ha}$ (setara 40 $\mathrm{kg} /$ petak) sebesar 249,96 gram. Sedangkan rata-rata berat basah per tongkol tanpa klobot tanaman jagung yang paling terendah sebesar 159,27 gram di capai pada perlakuan $\mathrm{P}_{0}$ yaitu perlakuan tanpa pemupukan petroganik.

Adanya perbedaan berat basah per tongkol tanpa klobot pada tanaman jagung diduga karena penambahan dosis petroganik menyebabkan bertambah pula jumlah daun jagung, karena daun adalah tempat proses fotosintesis yang menghasilkan zat makanan utama guna pertumbuhan. Dengan memberikan nitrogen akan meningkatkan pertumbuhan vegetatif diantaranya adalah daun, semakin tinggi luas permukaan daun maka akan semakin tinggi pertumbuhan dan hasil yang diperoleh. Menurut Harjadi (1991) besarnya jumlah daun dan luas daun akan berakibat tidak berimbangnya periode vegetatif dan generatif. Selain menambah unsur hara dari sumber pupuk petroganik juga akan mampu menciptakan kondisi fisik tanah yang ideal bagi pertumbuhan tanaman.

\begin{tabular}{ccc} 
Tabel 4b. Pengaruh Perlakuan Pembumbunan terhadap Jumlah Berat Basah per Tongkol Tanpa Klobot (gram). \\
\hline Perlakuan & $\begin{array}{c}\text { Rata-rata Berat Basah per Tongkol } \\
\text { Tanpa Klobot (gram) }\end{array}$ \\
\hline Pembumbunan (B) & 201,13 & a \\
B1 & 210,89 & a \\
B2 & 223,62 & a \\
B3 & \\
\hline Keterangan : angka yang didampingi huruf yang sama menunjukkan tidak beda nyata (Duncan's Test $5 \%)$.
\end{tabular}

Dari tabel di atas menunjukkan bahwa perlakuan pembumbunan terhadap berat basah per tongkol tanpa klobot tanaman jagung tidak menunjukkan beda nyata Pengaruh perlakuan pembumbunan terhadap rata-rata berat basah per tongkol tanpa kelobot tanaman jagung tertinggi pada perlakuan $\mathrm{B}_{3}$ yaitu pembumbunan 3 kali pada umur 3, 6, dan 9 minggu sebesar 223,62 gram. Sedangkan rata-rata berat basah per tongkol tanpa klobot tanaman jagung yang paling terendah sebesar 201,13 gram dicapai pada perlakuan $B_{1}$ yaitu perlakuan pembumbunan 1 kali pada umur 3 minggu saja.

Penerapan teknik pembumbunan yang tepat dan efektif sedini mungkin sangat bermanfaat sekali pada tanaman membantu penggemburan tanah dengan tujuan mempermudah akar untuk terus berpenetrasi menghisap unsur hara, akan tetapi dapat juga memberikan ruang biota tanah untuk hidup seperti cacing tanah. Selain itu, pada periode vegetatif tanaman akan menyerap sebanyak-banyaknya unsur hara yang ada di dalam tanah untuk perkembangan akar, daun, biji dan batang, hal tersebut akan mempengaruhi hasil produksi jagung yang tinggi pula.

\section{E. Jumlah Berat Kering per Tongkol Tanpa Klobot (gram)}

Berdasarkan hasil analisis menunjukkan bahwa antara perlakuan dosis pupuk petroganik dan pembumbunan terhadap ratarata berat kering per tongkol tanpa klobot tanaman jagung tidak menunjukkan adanya interaksi. Hasil pengamatan dosis pupuk 
Website : http://agritek.unmermadiun.ac.id/index.php/agritek

petroganik dan pembumbunan terhadap rata-rata jumlah berat kering per tongkol tanpa klobot tanaman jagung ditunjukkan pada tabel di bawah ini.

Tabel 5a. Pengaruh Perlakuan Dosis Pupuk Petroganik terhadap Jumlah Berat Kering per Tongkol tanpa Klobot (gram).

\begin{tabular}{ccc}
\hline Perlakuan & $\begin{array}{c}\text { Rata-rata Berat Kering per Tongkol } \\
\text { Tanpa Klobot (gram) }\end{array}$ \\
\hline $\begin{array}{c}\text { Dosis Petroganik (P) } \\
\text { P0 }\end{array}$ & 134,27 & $\mathrm{c}$ \\
P1 & 195,76 & $\mathrm{~b}$ \\
P2 & 209,96 & \\
\hline S.e & 8,52 & \\
\hline Keterangan : angka yang didampingi huruf yang sama menunjukkan tidak beda nyata (Duncan's Test 5\%).
\end{tabular}

Tabel di atas menunjukkan bahwa perlakuan antara $\mathrm{P}_{2}$ berbeda nyata dengan perlakuan $\mathrm{P}_{0}$, perlakuan $\mathrm{P}_{2}$ berbeda nyata dengan perakuan $P_{1}$, dan perlakuan $P_{0}$ berbeda nyata dengan perlakuan $P_{1}$. Pengaruh perlakuan dosis pupuk petroganik terhadap rata-rata berat kering per tongkol tanpa klobot tanaman jagung tertinggi pada perlakuan $\mathrm{P}_{2}$ yaitu dosis pemupukan $500 \mathrm{~kg} / \mathrm{ha}$ (setara 40 $\mathrm{kg} /$ petak) sebesar 209,96 gram. Sedangkan rata-rata jumlah berat kering per tongkol tanpa klobot tanaman jagung yang paling terendah sebesar 134,27 gram dicapai pada perlakuan $\mathrm{P}_{0}$ yaitu perlakuan tanpa pemupukan petroganik.

Adanya perbedaan jumlah berat kering per tongkol tanpa klobot pada tanaman jagung karena penambahan dosis petroganik menyebabkan bertambah pula jumlah daun jagung. Dengan memberikan nitrogen akan meningkatkan pertumbuhan vegetatif diantaranya adalah daun, semakin tinggi luas permukaan daun maka akan semakin tinggi pertumbuhan dan hasil yang diperoleh. Selain menambah unsur hara dari sumber pupuk petroganik juga akan mampu menciptakan kondisi fisik tanah yang ideal bagi pertumbuhan tanaman.

\begin{tabular}{ccc} 
Tabel 5b. Pengaruh Perlakuan Pembumbunan terhadap Jumlah Berat Kering per Tongkol Tanpa Kelobot (gram). \\
\hline Perlakuan & \multicolumn{2}{c}{$\begin{array}{c}\text { Rata-rata Berat Kering per Tongkol } \\
\text { Tanpa Kelobot (gram) }\end{array}$} \\
\hline $\begin{array}{c}\text { Pembumbunan (B) } \\
\text { B1 }\end{array}$ & 169,24 & b \\
B2 & 179,00 & b \\
B3 & 191,73 & a \\
\hline
\end{tabular}

Dari tabel di atas menunjukkan bahwa perlakuan antara $B_{3}$ berbeda nyata dengan perlakuan $B_{1}$, Pelakuan $B_{2}$ tidak berbeda nyata dengan perakuan $B_{1}$, dan perlakuan $B_{1}$ berbeda nyata dengan perlakuan $B_{3}$. Pengaruh perlakuan pembumbunan terhadap rata-rata jumlah berat basah per tongkol tanpa kelobot tanaman jagung tertinggi pada perlakuan $\mathrm{B}_{3}$ yaitu pembumbunan 3 kali pada umur 3, 6, dan 9 minggu sebesar 191,73 gram. Sedangkan rata-rata jumlah berat basah per tongkol tanpa kelobot tanaman jagung yang paling terendah sebesar 169,24 gram di capai pada perlakuan $\mathrm{B}_{1}$ yaitu perlakuan pembumbunan 1 kali pada umur 3 minggu saja.

Selain itu penerapan teknik pembumbunan yang tepat dan efektif sedini mungkin sangat bermanfaat sekali pada tanaman. Karena pada periode vegetatif tanaman menyerap sebanyak-banyaknya unsur hara yanga ada di dalam tanah untuk perkembangan akar, daun dan batang, hal tersebut akan mempengaruhi hasil produksi jagung yang tinggi pula. Aerasi tanah yang seimbang juga akan mendorong penyerapan hara menjadi lebih baik dan nantinya akan menghasilkan perkembangan serta hasil produksi yang optimal dari tanaman jagung.

\section{F. Jumlah Berat Basah 100 Biji (gram)}

Berdasarkan hasil analisis menunjukkan bahwa antara perlakuan dosis pupuk petroganik dan pembumbunan terhadap ratarata berat basah 100 biji tanaman jagung menunjukkan adanya interaksi. Hasil pengamatan pengaruh dosis pupuk petroganik dan pembumbunan terhadap rata-rata berat basah 100 biji tanaman jagung dapat dilihat pada tabel di bawah ini.

Tabel 6. Pengaruh Perlakuan Dosis Petroganik Dan Pembumbunan terhadap Jumlah Berat Basah 100 Biji Tanaman Jagung (gram).

\begin{tabular}{|c|cc|}
\hline Kombinasi Perlakuan & Rata-rata Berat Basah 100 Biji (gram) \\
\hline $\mathrm{P}_{0} \mathrm{~B}_{1}$ & 28,4 & $\mathrm{f}$ \\
$\mathrm{P}_{0} \mathrm{~B}_{2}$ & 28,6 & $\mathrm{f}$ \\
$\mathrm{P}_{0} \mathrm{~B}_{3}$ & 29,3 & $\mathrm{e}$
\end{tabular}


Website : http://agritek.unmermadiun.ac.id/index.php/agritek

\begin{tabular}{l|cc|}
$\mathrm{P}_{1} \mathrm{~B}_{1}$ & 30,5 & $\mathrm{~d}$ \\
$\mathrm{P}_{1} \mathrm{~B}_{2}$ & 32,1 & $\mathrm{c}$ \\
$\mathrm{P}_{1} \mathrm{~B}_{3}$ & 32,9 & $\mathrm{~b}$ \\
$\mathrm{P}_{2} \mathrm{~B}_{1}$ & 33,3 & $\mathrm{ab}$ \\
$\mathrm{P}_{2} \mathrm{~B}_{2}$ & 32,8 & $\mathrm{~b}$ \\
$\mathrm{P}_{2} \mathrm{~B}_{3}$ & 33,9 & $\mathrm{a}$ \\
\hline
\end{tabular}

Keterangan: Angka yang didampingi huruf yang sama menunjukkan tidak beda nyata pada kolom yang sama (Duncant Test (5\%)

Hasil pengamatan di atas menunjukkan bahwa perlakuan perlakuan dosis pupuk petroganik dan pembumbunan yang semakin meningkat menyebabkan perbedaan terhadap rata-rata berat basah 100 biji tanaman jagung. Pengaruh kombinasi dosis pupuk petroganik dan pembumbunan tanaman tertinggi dicapai pada kombinasi perlakuan $\mathrm{P}_{2} \mathrm{~B}_{3}$ yaitu dosis pupuk petroganik 500 $\mathrm{kg} / \mathrm{ha}$ (40kg/ petak) dan pembumbunan 3 kali pada umur 3, 6, dan 9 minggu dengan rata-rata berat basah 100 biji per petak tanaman jagung sebesar 33,9 gram yang berbeda nyata dengan perlakuan yang lain kecuali $\mathrm{P}_{2} \mathrm{~B}_{1}$ (dosis pupuk petoganik $500 \mathrm{~kg} / \mathrm{ha}$ dan pembumbunan 1 kali pada umur 3 minggu) dengan rata-rata jumlah berat basah 100 biji mencapai 33,3, sedangkan rata-rata berat basah 100 biji per sampel petak jagung terendah dicapai pada kombinasi $\mathrm{P}_{0} \mathrm{~B}_{1}$ yaitu kombinasi tanpa pupuk petroganik dengan perlakuan pembumbunan 1 kali umur 3 minggu dengan rata-rata jumlah biji per tongkol isi 28,4 gram.

Pemupukan petroganik yang dilakukan sebelum tanaman ditanam merupakan tahap persiapan lahan yang berfungsi memberikan nutrisi tambahan pada tanah sehingga unsur hara yang telah terkandung dalam tanah akan dapat berkombinasi dengan unsur yang ada pada pupuk petroganik. Dengan pupuk dasar yang sesuai dengan kesuburan tanah dan kebutuhan tanaman nantinya akan memberikan hasil panen yang optimal juga.

Dengan pemupukan dasar penerapan teknik pembumbunan yang tepat sedini mungkin akan menghasilkan perkembangan yang optimal dari tanaman budidaya. Hal ini dilakukan dengan tujuan agar tanaman yang diusahakan tidak berkompetisi dalam penyerapan unsur makanan yang terkandung di dalam tanah. Karena pada saat periode vegetatif tanaman terjadi perkembangan akar, daun dan batang sehingga tanaman akan lebih banyak menyerap unsur hara pada tanah. Hal tersebut bertujuan untuk pembentukan akar yang akan memperkokoh batang tanaman jagung dan pembentukan daun untuk tempat berfotosintesis menghasilkan makanan, bunga dan pengisian biji. Sehingga hasil produksi tanaman jagung yang diusahakan lebih optimal.

\section{G. Jumlah Berat Kering 100 Biji (gram)}

Berdasarkan hasil analisis sidik ragam menunjukkan bahwa antara perlakuan dosis pupuk petroganik dan pembumbunan terhadap rata-rata berat basah 100 biji tanaman jagung menunjukkan adanya interaksi.

Tabel 7. Pengaruh Perlakuan Dosis Petroganik Dan Pembumbunan terhadap Jumlah Berat Kering 100 Biji Tanaman Jagung (gram).

\begin{tabular}{|c|cc|}
\hline Kombinasi Perlakuan & Rata-rata Berat Kering 100 Biji (gram) \\
\hline $\mathrm{P}_{0} \mathrm{~B}_{1}$ & 20,4 & $\mathrm{~F}$ \\
$\mathrm{P}_{0} \mathrm{~B}_{2}$ & 20,6 & $\mathrm{Ef}$ \\
$\mathrm{P}_{0} \mathrm{~B}_{3}$ & 21,3 & $\mathrm{D}$ \\
$\mathrm{P}_{1} \mathrm{~B}_{1}$ & 21,8 & $\mathrm{c}$ \\
$\mathrm{P}_{1} \mathrm{~B}_{2}$ & 23,4 & $\mathrm{abc}$ \\
$\mathrm{P}_{1} \mathrm{~B}_{3}$ & 24,2 & $\mathrm{ab}$ \\
$\mathrm{P}_{2} \mathrm{~B}_{1}$ & 24,3 & $\mathrm{bc}$ \\
$\mathrm{P}_{2} \mathrm{~B}_{2}$ & 23,8 & $\mathrm{a}$ \\
$\mathrm{P}_{2} \mathrm{~B}_{3}$ & 24,9 & $\mathrm{c}$ \\
$\mathrm{c}$
\end{tabular}

Keterangan : Angka yang didampingi huruf yang sama menunjukkan tidak beda nyata pada kolom yang sama (Duncant Test (5\%)

Hasil pengamatan di atas menunjukkan bahwa perlakuan perlakuan dosis pupuk petroganik dan pembumbunan yang semakin meningkat menyebabkan perbedaan terhadap rata-rata berat kering 100 biji tanaman jagung. Pengaruh kombinasi dosis pupuk petroganik dan pembumbunan tanaman tertinggi dicapai pada kombinasi perlakuan $\mathrm{P}_{2} \mathrm{~B}_{3}$ yaitu dosis pupuk petroganik 500 $\mathrm{kg} / \mathrm{ha}$ (40kg/ petak) dan pembumbunan 3 kali pada umur 3,6, dan 9 minggu dengan rata-rata berat kering 100 biji per petak tanaman jagung sebesar 24,9 gram yang berbeda nyata dengan perlakuan yang lain kecuali $\mathrm{P}_{2} \mathrm{~B}_{1}$ dan $\mathrm{P}_{1} \mathrm{~B}_{3}$, sedangkan rata-rata 
Website : http://agritek.unmermadiun.ac.id/index.php/agritek

berat kering 100 biji tanaman jagung terendah dicapai pada kombinasi $\mathrm{P}_{0} \mathrm{~B}_{1}$ yaitu kombinasi tanpa pupuk petroganik dengan perlakuan pembumbunan 1 kali umur 3 minggu dengan rata-rata jumlah biji per tongkol isi 20,4 gram.

Berdasarkan peneletian menunjukkan bahwa penambahan dosis petroganik dan pembumbunan berpengaruh terhadap pertumbuhan berat kering 100 biji. Kandungan $\mathrm{C} / \mathrm{N}$ (perbandingan karbon dan nitrogen yang terkadung dalam bahan organik) yang terkandung dalam pupuk petroganik merupakan unsur yang di butuhkan tanaman untuk mempercepat dan meningkatkan tinggi tanaman, jumlah daun, pembungaan dan pembentukan biji. Unsur nitrogen diperlukan oleh tanaman jagung dengan dosis $15-20 \mathrm{~kg} / \mathrm{ha}$ pada awal pertumbuhan, serta diperlukan untuk pembentukan bunga dan pengisian biji pada periode vegetatif. Sehingga akan bermanfaat pada hasil produksi biji tanaman jagung.

Perbedaan tersebut juga disebabkan oleh proses pembumbunan yang bersifat menggemburkan tanah, sehingga tanah di daerah sekitar tanaman gembur dan memudahkan akar tanaman menyerap unsur hara dan air. Penyerapan unsur hara tersebut berpengaruh juga pada tanaman jagung karena tanaman jagung memerlukan intensitas cahaya matahari yang lebih tinggi sehingga tanaman ini dapat membentuk rantai carbon sebanyak 4 buah dalam menambat karbon dioksida $\left(\mathrm{CO}_{2}\right)$ dalam melangsungkan fotosintesis (Salisburi dan Ross, 1995).

\section{VI.KESIMPULAN DAN SARAN}

\section{A. Kesimpulan}

1. Terdapat interaksi antara perlakuan dosis petroganik $500 \mathrm{~kg} / \mathrm{ha}$ dan pembumbunan terhadap parameter jumlah berat basah 100 biji dan jumlah berat kering 100 biji, sedangkan untuk parameter tinggi tanaman, jumlah daun, jumlah biji per tongkol, berat basah tongkol tanpa kelobot dan berat kering tongkol tanpa kelobot tidak menunjukkan adanya interaksi.

2. Perlakuan penggunaan dosis pupuk petroganik pada parameter tinggi tanaman, jumlah daun, jumlah biji per tongkol, berat basah per tongkol tanpa kelobot dan berat kering per tongkol tanpa kelobot tertinggi $\mathrm{P}_{2}$ dan terendah $\mathrm{P}_{0}$. Perlakuan pembumbunan pada parameter tinggi tanaman untuk umur 15 hst, 30 hst dan 45 hst tertinggi $B_{3}$ dan terendah $B_{1}$. Pada parameter jumlah daun tanaman untuk umur 15 hst dan 30 hst tertinggi $\mathrm{B}_{2}$ dan terendah $\mathrm{B}_{3}$, sedangkan umur 45 hst tertinggi $\mathrm{B}_{3}$ dan terendah $\mathrm{B}_{1}$. Pada parameter jumlah biji per tongkol, berat basah per tongkol tanpa kelobot da berat kering per tongkol tanpa kelobot tertinggi $\mathrm{B}_{3}$ dan terendah $\mathrm{B}_{1}$.

3. Kombinasi perlakuan pada parameter berat basah dan berat kering 100 biji tertinggi dicapai $\mathrm{P}_{2} \mathrm{~B}_{3}$ dan terendah $\mathrm{P}_{0} \mathrm{~B}_{1}$.

\section{B. Saran}

Dari hasil penelitian yang dilakukan, perlu kiranya dilakukan penelitian lanjutan dengan menerapkan beberapa teknik pembumbunan sampai pada masa generatif dengan dosis pupuk yang berbeda, serta dilakukan pada lahan dan musim yang berbeda, sehingga dapat diperoleh informasi yang lebih akurat tentang saat pembumbunan dan dosis pupuk terhadap pertumbuhan dan produksi jagung (Zea may L.).

\section{DAFTAR PUSTAKA}

Andrianto dan Indarto. 2004. Budidaya dan Analisis Usaha Tani Jagung. Absolut.Yogyakarta.

Anonim.2013. Deputi Statistik Distribusi dan Jasa Badan Pusat Statistik. BPS Jakarta.

Belfield. Stephanie \& Brown, Christine. 2008. Field Crop Manual: Maize (A Guide to Upland Production in Cambodia). Canberra

Haryadi, S.1980. PengantarAgronomi.PT. Gramedia Jakarta.

Harjadi. S. S. 1991. PengantarAgronomi.PT. Gramedia. Jakarta.

Lamadji, M.J., L. Hakim, dan Rustidja. 1999. Akselerasi pertanian tangguh melalui pemuliaan nonkonvensional. (Prosiding Simposium V Pemuliaan Tanaman). PERIPI Komda Jawa Timur. p. 28-32.

Malti. Ghosh. Kaushik. Ramasamy. Rajkumar. Vidyasagar. 2011. Comparative Anatomy of Maize and its Application.(Intrnational Journal of Bio-resorces and Stress Management). 2(3):250-256

Purnomo. 2007. Budidaya 8 Jenis Tanaman Pangan. Penerbit Swadaya. Depok

Purwono dan H. Purnamawati. 2007. Budidaya 8 Jenis Tanaman Pangan Unggul. Penebar Swadaya. Jakarta. 139 hal.

Pristiadi. 2002. Pupuk dan Cara Pemupukan. Rineka Cipta, Jakarta.

Rochanidan Siti. 2007. Bercocok Tanam Jagung. Azka Press. Bogor

Rukmana dan Rahmat. 1997. Usaha Tani Jagung.Kanisius. Yogyakarta

Salisbury dan Ross. 1995. Fisiologi Tumbuhan Jilid Dua Biokimia Tumbuhan Edisi Keempat. Bandung: ITB.

Sukirno. 1985. Bertanam Jagung. Bima Cipta. Bandung

Souza, Castro, Pereira, Parentoni, 2009. Morpho-hanatomical Characterization of root $k$ \in Recurrent Selection Cycles for Food tolerance of Maize (Zea mays L.). Plant Soil Environ, 55(11):504-510.

Suhardi. 1983. Dasar-dasar Bercocok Tanan. Penerbit Kanisius. Yogyakarta. 